\title{
The economic valuation of mangrove ecosystem in Youtefa bay, Jayapura, Indonesia
}

\author{
Basa T. Rumahorbo ${ }^{1}$, Henderina J. Keiluhu ${ }^{1}$, Baigo Hamuna ${ }^{2 *}$ \\ ${ }^{1}$ Department of Biology, Cenderawasih University, Kamp Wolker Street, Jayapura 99351, Indonesia \\ ${ }^{2}$ Department of Marine Science and Fisheries, Cenderawasih University, Kamp Wolker Street, Jayapura 99351, \\ Indonesia \\ "e-mail: bhamuna@yahoo.com.sg
}

Received: December 2018 / Accepted: 30 January 2019

\begin{abstract}
The purpose of this research is understanding about the total economic value of mangrove ecosystem in the area of Youtefa bay, Jayapura, Papua. The data were collected directly by interviews. Data collection was conducted in March until April 2018 in the area located in three traditional villages around Youtefa bay namely Tobati (46 respondents), Enggros (82 respondents) and Nafri (100 respondents). The methods in this research are contingent valuation method, market price, replacement cost, benefit transfer and willingness to pay. The result of this research shows that total economic value of mangrove ecosystem is about USD 3,715,115.02 year ${ }^{-1}$ or about USD 15,937.49 ha $^{-1}$ year $^{-1}$. Nowadays, the communities in the three villages of Youtefa bay get direct use from the mangrove ecosystem are about USD 2,049,419.17 year $^{-1}$ or USD 3,987.1968 household ${ }^{-1}$ year ${ }^{-1}$. These direct use are derived from the utilization of mangroves as a supplier of fish, crab, shrimp, shellfish and firewood products. Indirect use of mangroves as coastal protection, prevention of seawater intrusion and carbon sequestration of USD 1,660,163.80 year ${ }^{-1}$ or USD 7,122.50 ha-1 year ${ }^{-1}$. The option and existence value of mangrove ecosystem are about USD 3,496.80 year ${ }^{-1}$ and USD 2,035.25 year ${ }^{-1}$. The conservation effort for the maintaining of mangrove ecosystem are needed to get the high value of the using it and improve the welfare of local communities.
\end{abstract}

Keywords: total economic value, contingent valuation method, direct use, indirect use, local community, Papua

\section{Introduction}

Mangrove as a biological natural resource has a various potential diversity for human life. The function of mangrove ecosystem are physical functions such as to keep the coastline being stable, to protect the coast from sea erosion or abrasion, to maintain seawater intrusion, to retain and deposit mud and to filter the contaminated materials. The other function is biological functions such as a hatchery for fish, shrimp, a place for nesting bird, a natural habitats for various types of biota, a shelter and spawning vari-

${ }^{*}$ corresponding author. ous types of shrimp, fish, and another biota. While the economic functions as a source of fuel, aquaculture, saltmaking, building materials and others (Valiela et al., 2001; Dahdouh-Guebas et al., 2005).

Most of the mangroves in the Jayapura City area are found in coastal areas of villages around the Youtefa bay area, such as Tobati, Enggros, Nafri, and Entrop villages. The type of mangrove in the area of Youtefa bay such as Sonneratia ovata, S. alba, Rhizophora mucronata, $R$. apiculata, $R$. stylosa, Avicennia alba, Xylocarpus granatum, Bruguiera gymnorrhiza, B. cylindrica (Hamuna et al., 2018c), S. caseolaris, Ceriops tagal (Handono et al., 2014), Derris trifolia and Lumnitzera littorea (Kalor et al., 2018). 
The mangrove area in Youtefa bay plays an important role for the communities around the Youtefa bay. The amount of benefits from the mangrove community sometimes leads to excessive exploitation and destruction of the mangrove areas. It can give an impact on decreasing of function of mangroves. Globally, mangrove is degrading quality and quantity and it is become endangered in the worldwide. For more than two decades (1980-2005) the world has lost more than $25 \%$ of the total area of mangrove (Giri et al., 2011). It just the same with the condition of mangrove in the area of Youtefa bay. The result of the research by Hamuna et al. (2018b) show that mangrove area in the coastal area of Jayapura city is a vulnerable area. This condition become a problem which the width of the cover mangrove area in Youtefa bay from 1967 is 511.24 ha, meanwhile at the year of 2017, the width of mangrove has been reduced to 233.12 ha (Hamuna \& Tanjung, 2018). The change of mangrove area is still ongoing until now because of the building activity in coastal area of Jayapura city such as build a ring road. This build can give an indirect and direct effect to the growing of mangrove ecosystem through mangrove logging and conversion of mangrove area become other designation (Handono et al., 2014; Hamuna \& Tanjung, 2018). The destruction and decrease of area mangrove can disturb the mangrove function and give impact to the economy incoming of communities around the mangrove area.

To anticipate the condition of destruction and reduction of mangrove area, it is necessary to give awareness to the community about the function and potential of mangrove ecosystem. One of the efforts are calculating the total economic value and benefits of mangrove ecosystem. The calculation will be a reference in utilization mangrove as one of an effort to conserve mangrove ecosystem. An assessment of valuation economic benefits of mangrove ecosystem has been done in Indonesia (Mangkay et al., 2013; Malik et al., 2015; Widiastuti et al., 2016; Sina et al., 2017).

The purpose of this research is to understand the total economic value of mangrove ecosystem in the area of Youtefa bay. The value of economic benefits of mangrove ecosystem consists of direct and indirect use value, option and existence value. The result of this research is becoming an information for the community and government to make a policy and policy making and also to manage the Natural Tourism Park of Youtefa bay. In addition, it can give a right utilization for Natural Tourism Park of Youtefa Bay as an ecological and economic benefit.

\section{Material and methods}

\section{1. Study Area}

This research was held in the area of Youtefa bay in Jayapura, Indonesia (Fig. 1), with the width area is about 233.12 ha (Hamuna \& Tanjung, 2018; Hamuna et al., 2018c). The data was collected from March to April

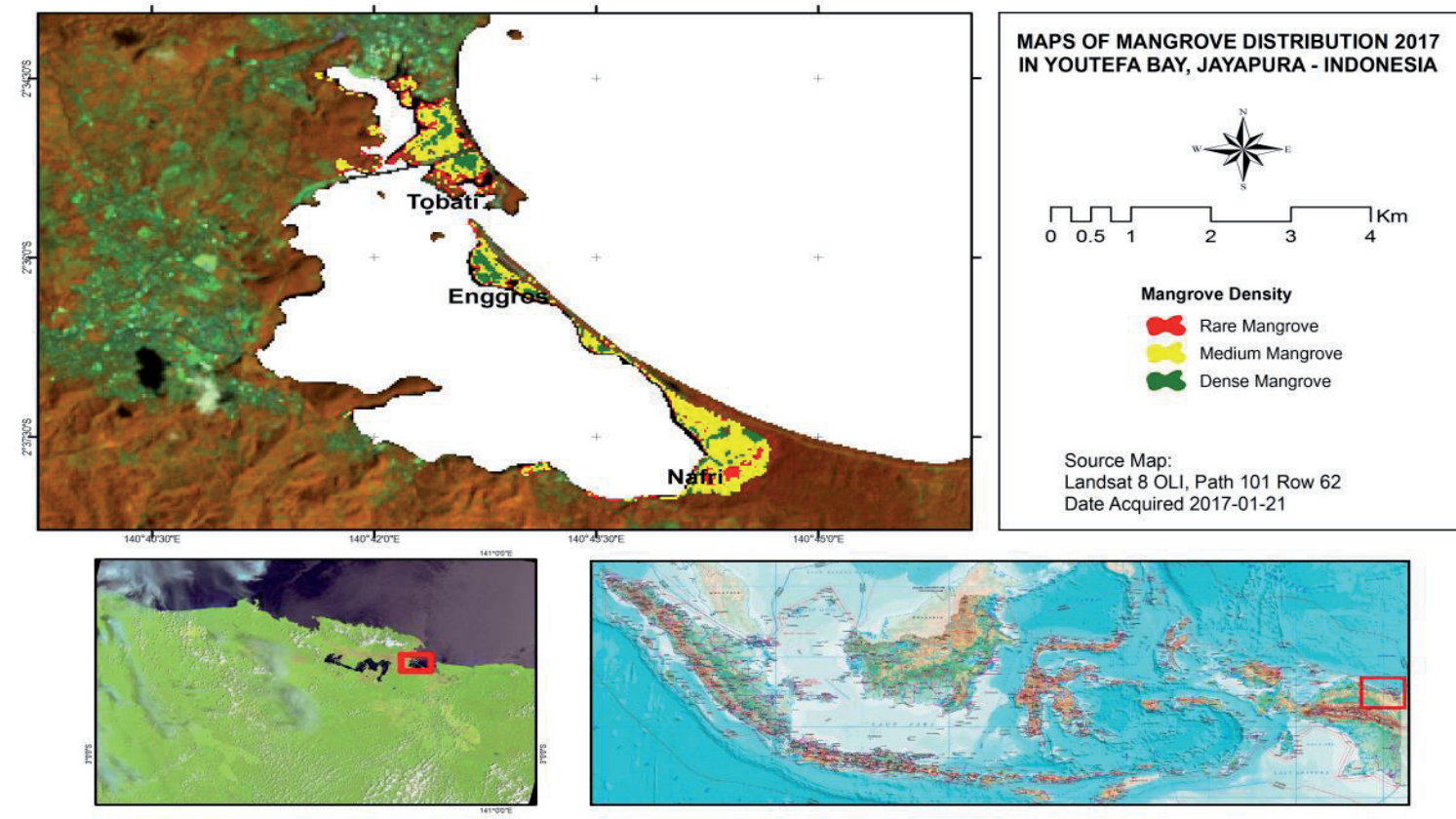

Figure 1. Map of the study area at Youtefa Bay, Jayapura, Indonesia 
2018 in three villages of the area of Youtefa bay such as Tobati Village, Enggros Village and Nafri village. This village are indigenous villages in Jayapura city and almost the communities work as traditional fishermen. In addition, the communities in these three villages have indigenous rights to utilize the area and natural resources of Youtefa bay.

\subsection{Data Collection}

The data were collected directly by interviews based on the questionnaire (questionnaire list). The categories of community as the respondents are the people who live in the Youtefa bay area. They are called as the beneficiaries of mangrove ecosystem or community who live in the coast as a fishermen, crabs seeker, shrimp and shellfish seeker (male and female). The number of households in the three villages are estimated 514 households. The total number of respondents in this research were 228 respondents (Tobati village are 46 respondents, Enggros village are 82 respondents and Nafri village are 100 respondents). They are consist of 150 men and 78 women.

\subsection{The Analysis of Economic Value of Mangrove Ecosystem}

The concept to estimate the economic value of mangrove ecosystem in Youtefa bay used Total Economic Value (TEV). In this research, TEV was obtained by summing all the benefits of identified mangrove ecosystem. The value of the benefits of the mangrove ecosystem consists of use value divided into direct and indirect use value and option value, while the non-use value consists of the existence value from mangrove ecosystem (Barbier, 1991). The identification of the direct use of mangrove ecosystem based on the current type of utilization of mangrove ecosystem by indigenous communities of Tobati, Enggros and Nafri villages. Meanwhile, indirect use are based on indigenous peoples' perceptions of the importance of mangrove ecosystem. The results of calculation of the value of economic benefits (IDR) of the mangrove ecosystem were converted to USD (USD $1=$ IDR 14,156 at May 18, 2018).

\section{Direct Use Value}

The direct use value is the value of the results mangrove ecosystem utilization directly by human beings, such as a provider of fish, crabs, shellfish and shrimp resources, it can also be used as firewood. Some assumptions used in the calculation of direct benefit value of mangrove ecosystem are: (1) all households in these three villages utilizing the mangrove ecosystem as resource area of fish, crab, shrimp, shell and firewood, (2) the total of productive days are 5 days (the activity of communities usually 4-6 days and there is no activity at Sunday, (3) the production cost consist of purchasing fuel and transportation cost to sell the produce in the market, especially for the activities of looking firewood didn't need production cost because it is only used for household needs.

To estimate the value of direct use of the mangrove ecosystem use the market price approach (Bann, 1998; Malik et al., 2015). The information on the production amount of each benefit form is obtained by using the Contingent Valuation Method (CVM). The formula to obtain the value of direct use the mangrove ecosystem as follows:

The value of fish valuation (FV), shellfish (SV) and shrimp $(\mathrm{ShV})$ :

FV; SV; ShV = Production $\left(\mathrm{kg}_{\mathrm{year}}{ }^{-1}\right) \times$ Price (USD

$\mathrm{kg}^{-1}$ ) - Production cost (USD year ${ }^{-1}$ )

The value of crab valuation $(\mathrm{CV})$ :

$\mathrm{CV}=$ Production $\left(\mathrm{crab}_{\mathrm{year}}{ }^{-1}\right) \times$ Price $\left(\mathrm{USD} \mathrm{crab}^{-1}\right)-$ Production cost (USD year-1)

The value of firewood valuation $(\mathrm{FwV})$ :

$\mathrm{FWV}=$ Wood collection (bundle year ${ }^{-1}$ ) $\mathrm{x}$ Price (USD bundle $e^{-1}$ )

\section{Indirect Use Value}

Indirect use value is the value of result indirect utilization of the mangrove ecosystem, such as coastal protection, sea intrusion prevention, carbon sequestration, nursery ground and feeding ground various types of fish and other biota. The methods that can be used to estimate the indirect use of mangroves are the method of replacement cost and benefits transfer.

The benefits of mangroves as coastal protection can be obtained by using the replacement cost method from the cost of making breakwater waves by Ministry of Public Work of the Republic of Indonesia (2014). The value of indirect use of mangroves as preventing sea water intrusion using replacement cost method (Mangkay et al., 2013; Malik et al., 2015). The value of indirect use of mangroves as a carbon stock provider can be obtained using the benefit transfer method. The value of mangrove use as a carbon stock provider was approached based on the result of estimation number of stock carton as the result of researches by Ong (1993).

\section{Option Value}

Option value usually use benefit transfer method. The method is approached by calculating the amount of biodiversity values in the mangrove ecosystem. The benefit 
value of mangrove ecosystem option in this research is based on the result of research mangrove biodiversity value in Bintuni Bay Regency, Papua (Ruitenbeek, 1992).

Existences Value

The value of existences value is assessed as the value of the existence of mangrove ecosystem. Some research show that the value of the existence of mangroves didn't have a market price, then used Willingness to Pay (WTP) method (Sina et al., 2017). WTP in this research refers to the willingness of respondents to contribute or pay the program in order to preserve sustainability and to repair or rehabilitation the mangrove ecosystem. WTP is obtained with a standard questionnaire by using CVM. With the application of the CVM, respondents are directly requested to determine the amount of money they are WTP (Ligus, 2018). The benefits of existence value of mangrove ecosystem is obtained by using the formula as follows:

$$
E V=\left[\sum_{i=0}^{n} E V_{i}\right] / n
$$

where, $E V=$ existences value; $E V_{i}=$ existences value form respondent to- $i ; n=$ number of respondents.

\section{Results and discussion}

\section{1. Direct Use Value (DUV)}

The direct use of mangrove ecosystem obtained by Tobati, Enggros and Nafri villagers as a resource provision for fish, crabs, shrimp, shellfish and firewood. Almost every day (except Sundays) people in the Youtefa bay (Tobati, Enggros and Nafri villages) do activities to find fish, crabs, shrimp and shellfish in the mangrove area. Based on the calculation of the number of fish, crabs, shellfish and snails multiplied by the number of productive days and the number of households, the total fish products are $25,179.21 \mathrm{~kg}$ month $^{-1}$ or $302,150.48 \mathrm{~kg}$ year $^{-1}$, total crab production as much as $34.631 .21 \mathrm{crab} /$ month or $415,574.47 \mathrm{crab}$ year 1, shrimp production as much as $14,159.25 \mathrm{~kg} \mathrm{month}^{-1}$ or $169,910.94 \mathrm{~kg} \mathrm{year}^{-1}$, and shell production as much as $16,261.09 \mathrm{~kg} \mathrm{month}^{-1}$ or $195,133.09 \mathrm{~kg}$ year $^{-1}$. The average production cost incurred are USD $35.32 \mathrm{month}^{-1}$ or USD 423.85 year $^{-1}$ for fishing activities and USD 28.26 month $^{-1}$ or USD 339.08 year $^{-1}$. Most fish, shrimp and shell catches are usually sold in stack units (not per $\mathrm{kg}$ ), and the weight of the products in one pile varies. From the results of rough estimates, the selling price for mixed fish is USD $1.77 \mathrm{~kg}^{-1}$, mangrove crab USD $1.41 \mathrm{crab}^{-1}$, shrimp USD $3.53 \mathrm{~kg}^{-1}$ and shell USD $1.41 \mathrm{~kg}^{-1}$. Based on the data of production amount, selling price of product and production cost can obtained the benefit of mangrove as a provider for fish product, crab, shrimp and shell product as follow for each product are USD 533,184.67 year $^{-1}$, USD 586,796.37 year $^{-1}$, USD 599,798.47 year $^{-1}$ and USD 275,350.51 year-1, respectively.

The utilization of mangrove wood as firewoods has been damaged as using as household purposes. This is a statement of almost all the respondents. The firewood usually sold with the average price about USD 0.71 if they need it. Total production of firewood for each household averaged 12.46 bundles month ${ }^{-1}$, so the total production of firewood for 514 households reached 6,404.44 bundles month $^{-1}$ or $76,853.28$ bundles year ${ }^{-1}$. If multiplied the amount of firewood production in a year with the market price of firewood, the direct benefits of mangrove will be obtained at USD 54,289.18 year ${ }^{-1}$.

Based on the calculation result of direct benefit mangrove ecosystem reach USD 2,049,419.17 year ${ }^{-1}$, where $26.02 \%$ comes from fish product benefit, $28.63 \%$ crab benefit, $29.27 \%$ of shrimp benefit, $13.14 \%$ shellfish benefit and $2.65 \%$ firewood benefit (Table 1). It proven that Youtefa bay were significant for economic life of indigenous community in Youtefa bay area directly. It can seen that every household can get benefit directly from mangrove is USD 3,987.20 household $^{-1}$ year $^{-1}$. The amount of mangrove benefits is especially for Papuan women because the mangrove area is place for food barn and a place for social and cultural interaction when looking for shell, shrimp and firewood in mangrove area. Some activities in the mangrove area is dominantly doing by women, that's why the mangrove area of Youtefa bay usually called as an ecosystem for women (Handono et al., 2014).

Table 1. The direct use value of mangrove ecosystem in Youtefa bay, Jayapura, Indonesia

\begin{tabular}{|c|c|c|c|}
\hline \multirow{2}{*}{ Products } & \multicolumn{3}{|c|}{ Direct use value } \\
\hline & USD year $^{-1}$ & $\begin{array}{c}\text { USD ha' } \\
{ }^{1} \text { year }^{-1}\end{array}$ & $\begin{array}{c}\text { USD household } \\
{ }^{1} \text { year-1 }\end{array}$ \\
\hline Fish & $533,184.66$ & $2,287.17$ & 1037.32 \\
\hline Crab & $586,796.37$ & $2,517.14$ & 1141.63 \\
\hline Shrimp & $599,798.47$ & $2,572.92$ & 1166.92 \\
\hline Shells & $275,350.51$ & $1,181.15$ & 535.70 \\
\hline Firewood & $54,289.16$ & 232.88 & 105.62 \\
\hline Total DUV & $2,049,419.17$ & $8,791.26$ & $3,987.20$ \\
\hline
\end{tabular}

\subsection{Indirect Use Value (IUV)}

Indirect use value of mangrove was calculated in this research consist of coastal protection, prevention of sea water intrusion and carbon stock providers. To estimate 
the value of mangrove benefits as coastal protection is used replacement cost approach. It used a cost of making a wave retaining embankment or breakwater. The cost of making the embankment with the size of $50 \mathrm{~m} \times 1.5 \mathrm{~m}$ $\mathrm{x} 2.5 \mathrm{~m}$ which it can be strength until 5 years reached USD 20,626,87 (IDR 291,994,000.00) or about USD 412.5374 meters $^{-1}$ (Ministry of Public Works of The Republic of Indonesia 2014). Based on the result of analysis show that the length coastline of mangroves in Youtefa bay area is about $16,945.07$ meters. It means that the value of mangrove as coastal protection obtained about USD $6,990,475.80$ or about USD 1,398,095.16 year ${ }^{-1}$.

The value of mangrove benefits as coastal protection in this research is higher than the estimation results in another research. The benefits of mangroves as a coast protector in Southern Thailand amounted to USD 3,679 ha-1 (Sathirathai \& Barbier, 2001). The case almost similar with the value of mangrove benefits as a coast protector in Takalar, South Sulawesi, Indonesia amounts to USD 3,767.00 ha $^{-1}$ (coastline length $=74,000$ meters; mangrove area $=1,719$ ha) (Malik et al., 2015). The value of mangrove benefits in Tatapaan, South Minahasa, Indonesia as coast protector is only USD $27.14 \mathrm{ha}^{-1}$ (IDR 106,291,110 year ${ }^{-1}$; coastline length $=75$ meters; mangrove area $=276.7$ ha) (Mangkay et al., 2013). Basically, the ratio of coastline length to mangrove and width mangrove area is the cause of different estimation of mangrove benefit value as coast protector. The estimation results of mangrove benefits as a higher coast protector is in the Fiji Islands ranged between USD $88 \mathrm{ha}^{-1}$ to USD $6.1 \mathrm{M} \mathrm{ha}^{-1}$ (Atkinson et al., 2016).

The benefits of mangrove as a prevention of sea water intrusion can be approached by using replacement cost toward clean water consumption. Every household in Tobati, Enggros and Nafri villages consumes 1 gallon of water at a price of USD 0.35 gallon $^{-1}$ (IDR 5,000 gallon ${ }^{-1}$ ). It conclude that the expenditure of each household in one year (365 days) spend the clean water as a basic need about USD 128.92 household $^{-1}$ year $^{-1}$. The number of households in the three villages are 514. It means that the value of mangrove benefit as a prevention of sea water intrusion reached USD 69,744.64 year ${ }^{-1}$.

Some result of the research show that the types of different mangrove can act as a provider of carbon stock in nature (Ong, 1993; Gevaña et al., 2008; Hong et al., 2017). Mangroves were founds to be the most carbon-rich ecosystem (Hong et al., 2017). In this research, the indirect use value of mangrove as a provider of carbon stocks was approached with the results of a research conducted by Ong (1993). The result of his research indicate that one square hectare of mangroves has a potential become a carbon stock provider of 100 to 200 tons $\mathrm{C} \mathrm{ha}^{-1}$. Relate to the condition of mangrove in Youtefa bay dominated by medium density (Hamuna \& Tanjung, 2018; Hamuna et al., 2018c), it caused that the value of mangrove as a carbon stock provider is determined by using the middle value of carbon stock in mangroves (150 tons $\left.\mathrm{C} \mathrm{ha}^{-1}\right)$. The economic value is obtained by multiplying the carbon stock's potential to the carbon price which provided by Diaz et al. (2011) reached USD 5.5 tons $^{-1} \mathrm{CO}_{2}$. That's why the value of mangrove benefits in Youtefa bay area as a carbon stock provider reached USD 192,324.00 or USD $825.00 \mathrm{ha}^{-1}$.

Based on the calculation results of indirect benefit mangrove ecosystem reached USD 1,660,163.80 year $^{-1}$ or 7,122.50 ha-1 year $^{-1}$ (Table 2). Indirect benefits of mangrove ecosystem derived from the benefits of mangroves as coast protector $(84.21 \%)$, prevention of sea water intrusion $(4.20 \%)$ and provider of carbon stock (11.58\%). The results of the research by Salem \& Mercer (2012) show that it has same results, data indicate that the comparison of indirect benefit mangroves as coastal protection is greater than mangrove benefits as a carbon stock which it reached USD 10.45 ha $^{-1}$ year $^{-1}$ to USD 8,044 ha $^{-1}$ year $^{-1}$ and USD 39.89 ha $^{-1}$ year $^{-1}$ to USD 4,265 ha ${ }^{-1}$ year $^{-1}$, respectively. It just same with the research by Malik et al. (2015), data indicate that the benefits of mangrove as coast protector reached to USD $694 \mathrm{ha}^{-1}$ year $^{-1}$ to USD 3,767 ha-1 year-1 compared to benefits of mangrove as a seawater intrusion prevention and carbon stock provider reached to USD $277 \mathrm{ha}^{-1}$ year $^{-1}$ and USD $550 \mathrm{ha}^{-1}$ year ${ }^{-1}$ to USD 1,100 ha${ }^{1}$ year $^{-1}$, respectively.

Table 2. The indirect use value of mangrove ecosystem in Youtefa bay, Jayapura, Indonesia

\begin{tabular}{|c|c|c|}
\hline \multirow{2}{*}{ Products } & \multicolumn{2}{|c|}{ Indirect use value } \\
\cline { 2 - 3 } & USD year & ${\text { USD } \text { ha }^{-1} \text { year }^{-1}}^{-1}$ \\
\hline Coastal protection & $1,395,925.74$ & $5,988.01$ \\
\hline $\begin{array}{c}\text { Prevention of seawater } \\
\text { intrusion }\end{array}$ & $65,663.50$ & 281.67 \\
\hline Carbon sequestration & $192,324.00$ & 825.00 \\
\hline Total IUV & $1,653,913.24$ & $7,094.68$ \\
\hline
\end{tabular}

\subsection{Option Value}

The option use value of mangrove ecosystem in Youtefa bay using benefit transfer method approach by assessing benefit estimates from another places (resources are available). The method is approached by calculating the benefits of biodiversity in the mangrove area. Indonesian mangrove ecosystem has biodiversity value reached USD 15 ha $^{-1}$ year $^{-1}$ (Ruitenbeek, 1992). This value can be used in all Indonesia mangrove if ecologically and naturally still exist. The width of mangrove area in Youtefa bay area is 233.12 ha and the biodiversity benefit of mangrove ecosystem is 
obtained at USD 3,496.80 year ${ }^{-1}$. The prediction toward the value benefits of mangrove biodiversity in this research will be decrease along with the high level of coastal area. It caused of the utilization of it used for another purposes such as build infrastructure and population growth of Jayapura city.

\subsection{Existences Value}

The existence value of mangrove ecosystem is obtained from understanding the value of WTP from the communities and the existence of mangrove. Based on the data in the field, 212 respondents are willing to contribute or pay the mangrove conservation and rehabilitation program. Otherwise, 16 respondents are not willing to contribute or pay the program because the mangrove conservation and rehabilitation program is responsibility of government and also less of economy incoming become the reason of community not to contribute the mangrove conservation program.

The value of WTP respondents obtained between from USD 0 to USD 14.11 (average WTP about USD 3.96 year ${ }^{1}$ for a respondent). If the average WTP multiplied by the number of households in the three villages (Tobati, Enggros and Nafri), the WTP obtained for USD 2,035.25 year ${ }^{-1}$ or USD 8.73 ha $^{-1}$ year-1 $^{-1}$. The high value of WTP shows that the communities get a great economy benefit and make the communities appreciate or respect the existence value of ecosystem mangrove (Widiastuti et al., 2016; Hamuna et al., 2018a). The value of WTP reached USD $8.73 \mathrm{ha}^{-1}$ year $^{-1}$ is higher than the WTP value of mangrove ecosystem existence in other regions in Indonesia. The results by Sina et al. (2017) obtained the average of WTP for the existence of mangroves in the coastal areas of Pulokerto reached to USD 1.87 ha $^{-1}$ year $^{-1}$. However, the value of WTP in this research is lower than the WTP of USD 21.43 ha $^{-1}$ year $^{-1}$ for the value of mangrove existence in Malind, Merauke and Naukenjerai, Papua, Indonesia (Widiastuti et al., 2016).

\subsection{The Total Economic Value (TEV) of Mangrove Ecosystem in Youtefa Bay, Jayapura}

The mangrove ecosystem in Youtefa bay, Jayapura has a great potential of natural resources. It can be seen from the amount of TEV mangrove ecosystem in this research. TEV mangrove ecosystem in Youtefa bay reached USD $3,715,115.02$ year-1 $^{-1}$ or equivalent to USD $15,937.49$ ha ${ }^{1}$ year $^{-1}$ (Table 3). If it compared with all economic values of mangroves based on benefit category, the value of direct use has a greater value (about 55.164\%) than the value of another benefits. The high value of direct benefits caused by the willingness of the community to exploit the natural resources for economic needs and improve the welfare of their lives. The results of this study also show ecologi- cal function of mangrove ecosystem in Youtefa bay (indirect use equal to $44.487 \%$ ). The option value reached to $0.094 \%$ and the existence value reached to $0.055 \%$ of the total value of mangrove economy in the area of Youtefa bay.

Table 3. Total economic value of mangrove ecosystem in Youtefa bay, Jayapura, Indonesia

\begin{tabular}{|c|c|c|}
\hline \multirow{2}{*}{$\begin{array}{c}\text { Category of economic } \\
\text { value }\end{array}$} & \multicolumn{2}{|c|}{ Total value } \\
\cline { 2 - 3 } & USD year & ${\text { USD } \text { ha }^{-1} \text { year }^{-1}}^{-1}$ \\
\hline Direct use value: & $2,049,419.17$ & $8,791.26$ \\
\hline Indirect use value: & $1,660,163.80$ & $7,122.50$ \\
\hline $\begin{array}{c}\text { Option value } \\
\text { (biodiversity value) }\end{array}$ & $3,496.80$ & 15.00 \\
\hline Existence value & $2,035.25$ & 8.73 \\
\hline Total Economic Value & $3,715,115.02$ & $15,937.49$ \\
\hline
\end{tabular}

TEV of mangrove ecosystem in this research is in the range of mangrove ecosystem in Indonesia The economic value of mangrove utilization in Indonesia ranges between USD $12.71 \mathrm{ha}^{-1}$ to USD $975.76 \mathrm{ha}^{-1}$, while the total economic value of mangrove ecosystem ranges between USD 3,624.98 ha $^{-1}$ year $^{-1}$ to USD 26,734.61 ha $^{-1}$ year $^{-1}$ (Rizal et al., 2018). The economic benefit value are direct use value, indirect use value, option value, existence value of mangrove. TEV of mangrove ecosystem (USD 15,937.4920 ha${ }^{1}$ year $\left.^{-1}\right)$ in this research is relatively high when compared to TEV of mangrove ecosystem in some areas in Indonesia (Mangkay et al., 2013; Malik et al., 2015; Widiastuti et al., 2016). Globally, TEV of mangrove ecosystem on some research results is estimated at USD 181 billion or USD $10,000 \mathrm{ha}^{-1}$ (Alongi, 2002). The benefits of mangroves as production output, water supply, disturbance regulation, environmental purification, gas regulation, and biodiversity support have the potential benefit value reached to USD 8,000 ha $^{-1}$ year $^{-1}$ (Tong et al., 2007). Generally, the differences of TEV in some research depend on the quantity of identified and quantified mangrove benefits and the condition and extent of the mangrove area.

The TEV of the mangrove ecosystem of Youtefa bay, Jayapura in this research is predicted become increase if all the economic benefits of the mangrove ecosystem can be identified and qualified. Another benefits of direct economic value include the benefits of recreational areas and mangrove wood as building materials, etc. (Salem \& Mercer, 2012). Otherwise, the indirect benefits are potential as fish and biota habitats (nursery ground, feeding ground, spawning ground) (Salem \& Mercer, 2012; Malik et al., 2015; Sina et al., 2017) and mangrove potential as a health pharmaceutical ingredient (Malik et al., 2015). 


\section{Conclusions}

TEV of mangrove ecosystem in Youtefa bay, Jayapura, Indonesia in this research is highly qualified. TEV mangrove ecosystem in this research are estimated to become increase if all the economic benefits of mangrove ecosystem can be identified and qualified. The highest value benefit are derived from the direct benefits of mangrove ecosystem as a supplier of fish products, crabs, shrimp, shellfish and firewood products. They can improve the economy of communities in Tobati, Enggros and Nafri villages directly. Meanwhile the indirect benefits of mangrove ecosystem are also quite high as coastal protection, prevention of seawater intrusion and carbon sequestration. The low value of benefits is derived from the option use (biodiversity use) and the existence use. The higher value of the benefits mangrove ecosystem need a conservation effort to maintain the mangrove ecosystem as the way to improve the welfare of local communities.

\section{Acknowledgements}

The author would like to thank the Ministry of Research, Technology and Higher Education of the Republic of Indonesia for funding this research (Grant No. 04/UN20.2.2/ PL/PDUPT/2018). Research members are thanked for field data collection.

\section{References}

Alongi D.M., 2002, Present state and future of the world's mangrove ecosystem. Environmental Conservation 29(3): 331-349.

Atkinson S.C., Jupiter S.D., Adams V.M., Ingram J.C., Narayan S., Klein C.J. \& Possingham H.P., 2016, Prioritising mangrove ecosystem services results in spatially variable management priorities. PLoS ONE 11(3): e0151992.

Bann C., 1998, The Economic Valuation of Mangroves: A Manual for Researchers. Economy and Environment Program for Southeast Asia (EEPSEA), Singapore.

Barbier E.B., 1991, An approach to economic evaluation of tropical wetlands: With examples from Guatemala and Nicaragua, [in:] Girvan N. P., Simons D. (eds), Caribbean Ecology and Economics. Caribbean Conservation Association, St. Michael, Barbados: 207-231.

Dahdouh-Guebas F., Jayatissa L.P., Di Nitto D., Bosire J.O., Lo Seen D. \& Koedam N., 2005, How effective were mangroves as a defense against the recent tsunami? Current Biology 15: 443-447.
Diaz D., Hamilton K. \& Johnson E., 2011, State of Forest Carbon Markets 2011: From Canopy to Currency. Forest Trend, Ecosystem Marketplace: Washington DC, USA.

Gevaña D.T., Pulhin F.B. \& Pampolina N.M., 2008, Carbon stock assessment of a mangrove ecosystem in San Juan, Batangas. Journal of Environmental Science and Management 11(1): 15-25.

Giri C.P., Ochieng E., Tieszen L.L., Zhu Z., Singh A., Loveland T. \& Duke, N., 2011, Status and distribution of mangrove ecosystem of the world using earth observation satellite data. Global Ecology and Biogeography 20(1): 154-159.

Hamuna B. \& Tanjung R.H.R., 2018, Deteksi perubahan luasan mangrove Teluk Youtefa Kota Jayapura menggunakan citra landsat multitemporal [Change detection of mangrove area in Youtefa bay, Jayapura city using multi-temporal landsat imagery]. Majalah Geografi Indonesia 32(2): 115-122.

Hamuna B., Rumahorbo B.T., Keiluhu H.J. \& Alianto, 2018a, Willingness to pay for existence value of mangrove ecosystem in Youtefa Bay, Jayapura, Indonesia. Journal of Environmental Management and Tourism 9(5): 907-915.

Hamuna B., Sari A.N. \& Alianto, 2018b, Kajian kerentanan wilayah pesisir ditinjau dari geomorfologi dan elevasi pesisir Kota dan Kabupaten Jayapura, Provinsi Papua [Study of coastal vulnerability assessed from coastal geomorphology and elevation of Jayapura City and Regency, Papua Province]. Jurnal Wilayah dan Lingkungan 6(1): 1-14.

Hamuna B., Sari A.N. \& Megawati R, 2018c, Kondisi hutan mangrove di kawasan Taman Wisata Alam Teluk Youtefa, Kota Jayapura [The condition of mangrove forest at Youtefa Bay Natural Park, Jayapura City]. Majalah Ilmiah Biologi Biosfera: A Scientific Journal 35(2): 75-83.

Handono N., Tanjung R.H.R. \& Zebua, L.I., 2014, Struktur vegetasi dan nilai ekonomi hutan mangrove Teluk Youtefa, Kota Jayapura, Papua [Vegetation structure and economic value of Youtefa Bay mangrove forest, Jayapura City, Papua]. Jurnal Biologi Papua 6(1): 1-11.

Hong L.C., Hemati Z.H. \& Zakaria R.M., 2017, Carbon stock evaluation of selected mangrove ecosystem in Peninsular Malaysia and its potential market value. Journal of Environmental Science and Management 20(2): 77-87.

Kalor J.D., Dimara L., Swabra O.G. \& Paiki K., 2018, Status kesehatan dan uji spesies indikator biologi ekosistem mangrove Teluk Youtefa Jayapura [Health status and test of biological indicator species of mangrove ecosystem at Youtefa Bay, Jayapura]. Majalah Ilmiah Biologi Biosfera: A Scientific Journal 35(1): 1-9. 
Ligus M., 2018, Measuring the willingness to pay for improved air quality: A contingent valuation survey. Polish Journal of Environmental Studies 27(2): 763-771.

Malik A., Fensholt R. \& Mertz O., 2015, Economic valuation of mangroves for comparison with commercial aquaculture in South Sulawesi, Indonesia. Forests 2015(6): 3028-3044.

Mangkay S.D., Harahab N., Polii B. \& Soemarno, 2013, Economic valuation of mangrove forest ecosystem in Tatapaan, South Minahasa, Indonesia, IOSR Journal of Environmental Science. Toxicology and Food Technology 5(6), 51-57.

Ministry of Public Works of the Republic of Indonesia, 2014. Lampiran Peraturan Menteri Pekerjaan Umum No. 11/2013, Pedoman Bahan Konstruksi Bangunan dan Rekayasa Sipil [Regulation of Ministry of Public Works No. 11/2013, on Guidelines for Building Construction Materials and Civil Engineering]. Ministry of Public Works of the Republic of Indonesia, Jakarta.

Ong J.E., 1993, Mangroves: A carbon source or sink. Chemosphere 27(6): 1097-1107.

Rizal A., Sahidin A. \& Herawati H., 2018, Economic value estimation of mangrove ecosystems in Indonesia. Biodiversity International Journal 2(1): 98-100.

Ruitenbeek H.J., 1992, Mangrove Management: An Economic Analysis of Management Options with a Focus on Bintuni Bay, Irian Jaya. Environmental Management Development in Indonesia Project (EMDI) Environmental Reports; School for Resource and Environ- mental Studies, Dalhousie University, Halifax, Nova Scotia, Canada and the Ministry of State for Population and Environment, Jakarta, Indonesia. Dalhousie University Printing Centre: Halifax, Nova Scotia, Canada.

Salem M.E. \& Mercer D.E., 2012, The economic value of mangroves: A meta-analysis. Sustainability 2012(4), 359-383.

Sathirathai S. \& Barbier E.B., 2001, Valuing mangrove conservation in Southern Thailand. Contemporary Economic Policy 19(2): 109-122.

Sina I, Maryunani, Batoro J. \& Harahab N., 2017, Analysis of total economic value of ecosystem mangrove forest in the coastal zone Pulokerto Village District of Kraton Pasuruan Regency. International Journal of Ecosystem 7(1): 1-10.

Tong C., Feagin R.A., Lu J., Zhang X., Zhang X., Wang W. \& Wenshan W., 2007, Ecosystem service values and restoration in the urban Sanyang wetland of Wenzhou, China. Ecological Engineering 29(3): 249-258.

Valiela I., Bowen J.L. \& York J.K., 2001, Mangrove ecosystem: One of the World's threatened major tropical environments. BioScience 51(10): 807-815.

Widiastuti M. M. D., Ruata N. N. \& Arifin T., 2016, Valuasi ekonomi ekosistem mangrove di wilayah pesisir Kabupaten Merauke [The economic valuation of mangrove ecosystem in coastal zone of Merauke Regency]. Jurnal Sosial Ekonomi Kelautan dan Perikanan 11(2): 147-159. 